\title{
Analysis of Judicial Policy in Deciding Criminal Acts Based Alternative Indictment (Case Study Decision Number 82 / Pid.B / 2019 / PN.Blora)
}

\author{
Nur Dwi Edie $\mathbf{W}^{1}$ and Gunarto ${ }^{2}$
}

Abstract: In the criminal justice system process the judge plays a role in implementing the decision in which the decision was taken in consideration of the indictments by the prosecutors. In alternative indictments each indictment is mutually exclusive. The judge will choose one of the charges proven according to his conviction. Therefore the alternative indictment is also called the indictment of choice (keuze telastelgging). This research formed the formulation of the problem namely how is the juridical implication of alternative forms of indictment in case number 82 / Pid.B / 2019 / PN.Blora and what is the basis of the judge's judgment in deciding case Number 82 / Pid.B / 2019 / PN.Blora with alternative indictment. This research uses juridical sociological methods with descriptive analysis research specifications. The data used for this study are secondary data with field observation methods and literature and document studies. Based on the research it was concluded (1) the preparation of the indictment in the case of verdict number 82 / Pid.B / 2019 / PN Bla based on Article 378 of the Criminal Code, with an alternative Article 372 of the Criminal Code. In this case, the element that eliminates one another is about the "existence" of the goods in the possession of the defendant. (2) In decision number 82 / Pid.B / 2019 / PN Bla, the judge considers that based on the legal facts revealed in the trial the defendant violated the criminal provisions as in the Second Indictment of alternative charges Article 378 of the Criminal Code Jo Article 64 paragraph 1 of the Criminal Code.

Keywords: Judge Policy; Criminal Decisions; Alternative Indictments.

\section{Introduction}

The 1945 Constitution of the Republic of Indonesia clearly states that the Indonesian state is a state of law. In line with these provisions, one of the principles of the rule of law is the guarantee of equality for everyone before the law (equality before the law). Therefore, everyone has the right to recognition, guarantees, protections and guarantees of fair legal certainty and equal treatment before the law. If an activity or act violates the provisions of the prevailing laws and regulations, then the offender will be subject to a sanction according to the regulations in violation. Law basically has a very important role in social life, because law is not only a parameter for justice, order, order and order, ${ }^{3}$

In its implementation in the legal system in Indonesia, Indonesia as a rule of law has several legal systems adhered to in it, one of which is the criminal law system. Criminal law is basically a set of written legal rules governing prohibited or prohibited acts, with the threat of certain sanctions that can be imposed if the prohibited acts

\footnotetext{
${ }^{1}$ Student of Master of Law, Universitas Islam Sultan Agung Semarang and Indonesian Police, email: dwiedi4@gmail.com

${ }^{2}$ Professor of Faculty of Law, Sultan Agung Islamic University (UNISSULA), Semarang

${ }^{3}$ Andi Hamzah, 2001, Bunga Rampai Hukum Pidana dan Acara Pidana, Jakarta: Ghalialndonesia, p. 14
} 
are committed. Because the basic concept of this rule is that every person or person who commits an act that is prohibited, it must be responsible for these actions. ${ }^{4} T$ The existence of criminal threats against people who violate the rules regarding prohibition of committing acts that are formulated in the Act is as a characteristic of a particular criminal act, which distinguishes the rules regarding prohibition of other acts that are not criminal acts. ${ }^{5}$

The court's decision handed down by the judge must be based on the indictment made by the Public Prosecutor which contains the facts that occurred in a crime (offense) along with the legal rules violated by the defendant. The Public Prosecutor must be careful and careful in making the contents of the indictment, which must meet both the formal and material requirements of the indictment as stated in Article 143 paragraph (2) point a of the Criminal Procedure Code. The indictment will be the basis for the hearing and decision making by the judge. In other words, a judge's decision in a criminal case is limited by what the public prosecutor has indicted.

The main purpose of the indictment is that the law wants to see the stipulation of the reasons on which the criminal charges have been committed must be properly listed. The defendant was blamed for violating a rule of criminal law, at a certain time and place and also stated the conditions when committing a crime. Mentioning time (tempus) and place (locus delecti) as well as circumstances indicate the indictment of certain events and actions, which are specialized and individualized. ${ }^{6}$

There is almost no literature that can be used as a reference about the definition of indictment. Generally the indictment is interpreted by legal experts in the form of a deed that contains the formulation or withdrawn or concluded from the results of the investigation investigated in connection with the article of a criminal offense that was violated and charged to the defendant, and the indictment is the basis of the examination for the judge in a court hearing. ${ }^{7}$

In compiling alternative indictments, several indictments were made, but only one was made. Usually this indictment is made if the public prosecutor is hesitant to apply which article of the defendant's actions are most appropriate for his mistakes. In these alternative charges each indictment is mutually exclusive. The judge will choose one of the charges proven according to his conviction. Therefore the alternative indictment is also called the indictment of choice (keuze telastelgging).

In decision Number 82 / Pid.B / 2019 / PN. Blora the public prosecutor has made an alternative indictment. In the alternative indictment the public prosecutor stated that the defendant was charged with two criminal acts including the first indictment namely intentionally and unlawfully owning something which is wholly or partly owned by another person, but that which is in his power is not due to a crime as regulated in Article 372 of the Criminal Code concerning Article embezzlement and the second indictment namely anyone with a view to benefiting himself or others

\footnotetext{
${ }^{4}$ Setiyono, 2010, Tips Hukum Praktis Menghadapi Kasus Pidana, Jakarta: Raih Asa Sukses, p. 10

${ }^{5}$ Adami Chazawi, 2001, Kejahatan Terhadap Tubuh dan Nyawa, Jakarta: RajaGrafindo Persada, p. 1-2.

6 Martiman Prodjohamidjojo, 2002, Teori dan Teknik Membuat Surat Dakwaan, Bogor: Ghalialndonesia, p. 32.

${ }^{7}$ M. Yahya Harahap, 1997, Pembahasan permasalahan dan penerapan KUHAP, volume 1, Jakarta: Sinar Grafika, p. 414.
} 
against the law, by using a false name or fake dignity, by deception, or a series of lies, moves others to hand over something to him, or to give debt or write off receivables as stipulated in Article 378 of the Criminal Code concerning Article fraudulent acts. Based on the description on the background of the problem above, then the problem formulation can be formed as follows: What are the juridical implications of alternative forms of indictment in case number 82 / Pid.B / 2019 / PN.Blora?; What is the basis for the judge's judgment in deciding case Number 82 / Pid.B / 2019 / PN. Blora with alternative charges?

\section{Research Methods}

To conduct a study in this study the writer uses the sociological juridical method (social legal research) to study and discuss the problems raised. Juridical is an approach that uses principles and legal principles derived from written regulations, sociological is an approach that aims to clarify the real conditions that exist and appear in the community to the problem under study or give importance to the steps of observation. This study uses descriptive research specifications analysis or the nature of the research object exposure. In this study the writer took the location in the Blora District Court. The data used for this research are secondary data. Secondary data is data obtained from library research consisting of primary legal materials. To obtain data in this study, data collection methods such as field observations and literature studies and document studies are used. The data that has been obtained is then analyzed by qualitative analysis, namely data analysis by not using numbers, but data obtained through research.

\section{2.. Results and Discussion}

\subsection{Juridical Implications of Alternative Forms of Indictment in Case Number 82 / Pid.B / 2019 / PN.Blora}

In the results of research conducted by the author in reference to criminal cases, the Blora District Court who tried a criminal case with a regular examination at the first court has ruled in the case of Defendant KASMIN Bin KASTUBI, Considering, that the Defendant was indicted by the Public Prosecutor based on indictment No. Reg. Perk. : PDM-29 / Blora / 05/2019 dated May 16, 2019 with alternative charges.

The first indictment- That the defendant Kasmin Bin Kastubi was at least Tuesday, September 5, 2017 at around 19.00 WIB at the defendant's house, Hamlet Balongan RT 001 / RW 016 Jiken District, Blora Regency or at least in a place that was included in the Blora District Court jurisdiction, consecutively have carried out several acts that have a relationship such that they must be seen as an act that continues intentionally and unlawfully owns goods that have a total price of approximately Rp. $161,200,000.00$ (one hundred sixty-one million two hundred thousand rupiah) wholly or partly belonging to another person, namely Br. Parmin Bin Ngaijan or at least does not belong to the accused, but the defendant's authority is not due to crime. Starting from the wishes of Br. Parmin bin Ngaijan who wanted to include his brother-in-law named Br. AM Efendi to members of the Army Tamtama so Br. Sajiman introduced 
him to the defendant. That from the introduction the defendant requested to give him some money as a condition for Br. AM. Efendi was accepted as a member of the Army, which is 21 transactions in stages. The defendant's actions fulfill the formulation and are threatened with criminal acts as regulated in Article 372 of the Indonesian Criminal Code Article 64 paragraph (1) of the Indonesian Criminal Code. ${ }^{8}$ Second Indictment The defendant's actions fulfill the formulation and are threatened with criminal acts as regulated in Article 378 of the Criminal Code Jo Article 64 paragraph (1) of the Criminal Code. ${ }^{9}$

In alternative drafting of this indictment an alternative is given which depends on how developments in the trial regarding which indictment are proven. Generally these indictments which are prepared in an alternative way the article eliminates each other in the sense that if certain elements have been proven the other elements must not be proven, and vice versa. The preparation of the indictment in case number 82 / Pid.B / 2019 / PN Bla based on Article 378 of the Criminal Code, with an alternative Article 372 of the Criminal Code.

In this case, the element that eliminates one another is about the "existence" of the goods in the possession of the defendant. If the existence of such items is in the possession of the defendant as a result of persuasion or a series of false words carried out by the defendant then in this case there has been a criminal offense that violates Article 378 of the Criminal Code. Whereas if the defendant's possession of the said item is not the result of persuasion or a series of false words carried out by the defendant, but with the permission or approval of the owner, then the defendant sells or pawns or in whatever way the defendant treats his goods as if they were his own. without the owner's permission, then in this case there was an offense of embezzlement violating Article 372 of the Criminal Code. Therefore, if it is proven to violate Article 378 of the Criminal Code it is impossible to also violate Article 372 of the Criminal Code, and vice versa; so it's impossible to prove both.

The alternative indictment in the case above explains that there are several indictments arranged in layers, one layer is an alternative and is to exclude the indictment on the other layer. This form of indictment is used if there is no certainty as to which crime is the most appropriate to prove. Although the indictment consists of several layers, but only 1 (one) charge will be proven. Proof of indictment need not be carried out in sequence according to the indictment layer, but directly to the indictment which is deemed proven. If one has been proven then the charges in the other layers do not need to be proven again. ${ }^{10}$

An alternative indictment in the implementation of the criminal justice process described in decision number 82 / Pid.B / 2019 / PN.Bla as a form of finding legal certainty that the judge will find in his considerations before convicting a criminal case.

\footnotetext{
${ }^{8}$ Decision Number 82 / Pid.B / 2019 / PN Bla

${ }^{9}$ Decision Number 82 / Pid.B / 2019 / PN Bla

${ }^{10}$ Moch. Faisal Salam, 2001, Hukum Acara Pidana Dalam Teori \& Praktek, Bandung: Mandar Maju, p. 201
} 


\subsection{Judge's Basic Considerations in Deciding Case Number 82 / Pid.B / 2019 / PN.Blora with Alternative Indictments}

In Decision Number 82 / Pid.B / 2019 / PN.Blora which contains alternative indictments in the demands of the Public Prosecutor generates judges' consideration in the form of Considering, that based on the legal facts revealed in the trial the defendant violated the criminal provisions as stated in the Second Indictment of Article 378 of the Criminal Code Jo Article 64 paragraph (1) of the Criminal Code whose elements are as follows: ${ }^{11}$

- Whose elements

Considering, that the trial was based on the statements of witnesses and the information of the Defendant that the Defendant himself had admitted that if the Defendant who was present and examined in this trial was the Defendant whose identity was in accordance with that contained in the indictment of the Public Prosecutor. Besides that the Defendant was able to attend the trial and was able to answer all the questions of the Panel of Judges smoothly then this element was fulfilled;

- Element with the intention to benefit oneself or others by breaking the law Considering, that based on the description above, the Defendant's actions several times requested a sum of money from witness Parmin to the amount of Rp.161,200,000.00 (one hundred sixty-one million two hundred thousand rupiah) so that witness AM Evendi could become a member of the Tamtama TNI AD but it turns out that up to now the witness AM Evendi cannot be a member of the Army Commander and the money amounting to Rp.161,200,000.00 (one hundred sixtyone million two hundred thousand rupiah) has not been returned by the defendant to the witness Parmin so that it is detrimental to the witness Parmin shows that the defendant's actions were carried out against the law and the Defendant's actions had benefited the Defendant. Considering, that based on the above mentioned considerations, this element has been fulfilled;

- Elements by using false names or fake dignity, with guile or a series of lies Considering, it turns out that the Defendant's words are false words that the Defendant deliberately said so that the witness Parmin believed in the Defendant and finally handed over Rp.161,200,000.00 (one hundred sixty one million two hundred thousand rupiah) to the Defendant. Considering, that based on the above mentioned considerations, this element has been fulfilled;

- The element moves others to hand over something to him or to give debt or write off receivables

Considering, that the words of the Defendant which said if the defendant had a Link or lane link at the Diponegoro Kodam IV Semarang so that witness AM Evendi could become a member of the Military Commander of the Army had moved the Parmin witness to hand over items in the form of money to the Defendant in the amount of Rp.161,200,000.00 ( one hundred sixty one million two hundred

${ }^{11}$ Decision Number 82 / Pid.B / 2019 / PN Bla 
thousand rupiah). Considering, that based on the above mentioned considerations, this element has been fulfilled;

- The elements of some actions are related in such a way that they must be seen as a continuing action

Considering whereas because all elements of the Second Indictment have been fulfilled, the Defendant has been proven legally and convincingly guilty of committing the crime of "continuing fraud";

Bearing in mind, Article 378 of the Criminal Code Jo Article 64 paragraph (1) of the Criminal Code, Law Number 8 of 1981 concerning the Criminal Procedure Code and other regulations relating to this case, states that the Defendant KASMIN Bin KASTUBI has been legally proven and convicted guilty of committing a crime "Continued fraud" as in the second indictment of the Public Prosecutor, convicting KASMIN Bin KASTUBI, therefore, with a 1 (one) year imprisonment.

In the verdict, the judge considered the facts in the trial where the Defendant fulfilled the elements in the second indictment as Article 378 of the Criminal Code Jo Article 64 paragraph (1) of the Criminal Code which as a fraudulent act benefited yourself or others against the law, using false names or fake dignity, with deception, or a series of lies, moving others to hand over something to him, or to give debt or write off receivables threatened with fraud with a maximum of four years imprisonment. However, the judge's consideration of the verdict weighed on mitigating circumstances which resulted in a 1-year sentence to the Defendant.

Legal certainty as outlined in a judge's decision is an outcome that is based on legal facts that are legally relevant and are considered with conscience. Judges are always required to always be able to interpret the meaning of the laws and regulations which are used as the basis for implementation. The application of the law must be in accordance with the case, so that the judge can construct the case being tried in its entirety, wise and objectively. ${ }^{12}$

\section{Closing}

\subsection{Conclusions}

- The preparation of the indictment in case number 82 / Pid.B / 2019 / PN Bla based on Article 378 of the Criminal Code, with an alternative Article 372 of the Criminal Code. In this case, the element that eliminates one another is about the "existence" of the goods in the possession of the defendant. If the existence of such items is in the possession of the defendant as a result of persuasion or a series of false words carried out by the defendant then in this case there has been a criminal offense that violates Article 378 of the Criminal Code. Whereas if the defendant's possession of the said item is not the result of persuasion or a series of false words carried out by the defendant, but with the permission or approval of

\footnotetext{
${ }^{12}$ Fence M. Wantu, 2012, Mewujudkan Kepastian Hukum, Keadilan dan Kemanfaatan dalam Putusan Hakim di Peradilan Perdata, Journal of Legal Dynamics, Vol. 12 No. September 3, 2012, Gorontalo: Faculty of Law, Gorontalo State University, p. 482-483
} 
the owner, then the defendant sells or pawns or in whatever way the defendant treats his goods as if it were his own property without the owner's permission, then in this case there was an embezzlement offense violating Article 372 of the Criminal Code. Therefore, if it is proven that it violates Article 378 of the Criminal Code it is impossible to also violate Article 372 of the Criminal Code, and vice versa; so it's impossible to prove both.

- In decision number 82 / Pid.B / 2019 / PN Bla, the judge considered that based on the legal facts revealed in the trial the defendant violated the criminal provisions as in the Second Indictment of alternative charges Article 378 of the Criminal Code Jo Article 64 paragraph (1) of the Criminal Code whose elements : (1) Whosoever elements, (2) Elements with the intention to benefit oneself or others by breaking the law, (3) Elements by using false names or false dignity, by guile or series of lies, (4) Elements of moving people others to surrender something to him or in order to give debt or write off receivables, and (5) The elements of some actions which are related in such a way that must be seen as a continuing act.

\subsection{Suggestions}

- In making alternative indictments the public prosecutor should be careful, thorough and alert. Avoid indictments that cause a lot of doubts in terms of both formal and material requirements and systematic, nature, style, and forms of criminal acts in the indictment;

- Considering that there is no uniformity in compiling indictments, the public prosecutor in drafting the indictment should be more careful and thorough in relinquishing the criminal elements charged, namely by paying attention to all the instructions and guidance in various products issued by the Attorney General and the attorney general's office. in the area;

\section{References}

\section{Book}

[1] Adami Chazawi, 2001, Kejahatan Terhadap Tubuh dan Nyawa, Jakarta: Raja Grafindo Persada

[2] Andi Hamzah, 2001, Bunga Rampai Hukum Pidana dan Acara Pidana, Jakarta: Ghalia Indonesia

[3] Martiman Prodjohamidjojo, 2002, Teori dan Teknik Membuat Surat Dakwaan, Bogor: Ghalia Indonesia

[4] Moch. Faisal Salam, 2001 , Hukum Acara Pidana Dalam Teori \& Praktek, Bandung: Mandar Maju

[5] M. Yahya Harahap, 1997, Pembahasan permasalahan dan penerapan KUHAP, volume 1, Jakarta: Sinar Grafika

[6] Setiyono, 2010, Tips Hukum Praktis Menghadapi Kasus Pidana, Jakarta: Raih Asa Sukses

\section{Regulations}

[1] The 1945 Constitution of the Republic of Indonesia 
[2] Criminal Law Book

[3] Criminal Procedure Code

\section{Journal}

[1] Fence M. Wantu, 2012, Mewujudkan Kepastian Hukum, Keadilan dan Kemanfaatan dalam Putusan Hakim di Peradilan Perdata, Journal of Legal Dynamics, Vol. 12 No. 3 September 2012, Gorontalo: Faculty of Law, Gorontalo State University

\section{Documents}

Decision Number 82 / Pid.B / 2019 / PN Bla 